\title{
Juridical Review of Income Tax Restitution (PPH) against Cancellation of Sale and Purchase Agreement Based on Government Regulation Number 34 of 2016
}

\author{
Alannuari Afid Amasi ${ }^{*}$, Akhmad Khisni ${ }^{* *}$ and Amin Purnawan ${ }^{* * *}$ \\ *) Student of Master of Notary Law, Faculty of Law, Universitas Islam Sultan Agung \\ (UNISSULA) Semarang, E-mail: alanuariafidamasi020190@gmail.com \\ $\left.{ }^{* *}\right)$ Lecturer of Master of Notary Law, Faculty of Law, Universitas Islam Sultan Agung \\ (UNISSULA) Semarang \\ ${ }^{* * *}$ Lecturer of Master of Notary Law, Faculty of Law, Universitas Islam Sultan Agung \\ (UNISSULA) Semarang
}

\begin{abstract}
The purpose of this study is to analyze: 1) The legal construction of the Sale and Purchase Binding Agreement which is the basis for the imposition of Income Tax (PPh). 2) Implementation of Sale and Purchase Agreement on Land Rights Related to the Imposition of Income Tax (PPh). 3) Procedure for Income Tax (PPh) refunds for the cancellation of the sale and purchase agreement based on Government Regulation Number 34 of 2016. The research resultsare: 1) The legal construction of the Sale and Purchase Agreement which is the basis for the imposition of Income Tax (PPh) is Income Tax Act Number 36 Of 2008 Article 4 paragraph 2 letter $d$. In this article, it is clearly stated that income obtained from transactions of transfer of rights to land and / or buildings may be subject to final income tax. The rate of Final Income Tax Article 4 paragraph 2 from transactions for the transfer of rights to land and / or buildings in general is 5\%. Meanwhile, the tax object is the income obtained from the transaction. 2). The implementation of the sale and purchase agreement on land rights related to the imposition of income tax (PPh) must be carried out in a clear manner, namely based on the agreement of both parties, and carried out with a PPAT deed, in this case a sale and purchase deed (AJB), after the requirements both material and formal have been met. 3. The Income Tax (PPh) restitution procedure for the cancellation of the sale and purchase agreement based on Government Regulation Number 34 of 2016, namely reporting, document verification, administrative research. The consequences of administrative sanctions in the form of an increase of $100 \%$ from the basis of tax determination if based on the results of the examination found a lack of tax payments.
\end{abstract}

Keywords: Buying and Selling; Tax Refunds; Income Tax.

\section{Introduction}

The rapid increase in demand for land accompanied by the current limited availability of land also has a major impact on increasing the value and price of land. This will create the potential for conflicts and problems related to or caused by land. regulate 
legal certainty in human relations with land. ${ }^{1}$ Registering land rights is important to ensure legal certainty for land rights holders and other parties with an interest in the land. land registration is carried out at the Land Office in the regency or municipality where the land is located. ${ }^{2}$ The implementation of land registration activities is regulated in Government Regulation of the Republic of Indonesia Number 10 of 1961 concerning Land Registration (hereinafter referred to as PP No.10 of 1961) and has been changed to Government Regulation of the Republic of Indonesia Number 24 of 1997 concerning Land Registration (hereinafter referred to as PP No. 24 years 1997). In carrying out its duties, the land office is assisted by the Official for Making Land Deeds (hereinafter referred to as PPAT) whose main task is to carry out part of the land registration activities by making deeds as evidence and basis for land registration.

Land registration is intended to provide certainty of rights and legal protection for land rights holders by proving land certificates, as an instrument for structuring land tenure and ownership and as a controlling instrument in the use and utilization of land. The registration of land rights is a guarantee from the State, and is an important instrument for the protection of landowners. Land registration is rechtkadaster which includes:

1. Measurement, mapping and land accounting activities

2. Registration of these rights

3. Issuance of valid land title certificates as a strong means of proof. ${ }^{3}$

One of the legal actions taken by PPAT is in terms of buying and selling land. Buying and selling is an effort to obtain land rights. Transfer of rights / transfer of rights, which is a legal act with the aim of transferring rights, including buying and selling, grants, exchange, separation and distribution of joint assets and income in companies or inbreng. The sale and purchase of land rights must be carried out before the PPAT. This is proof that there has been a sale and purchase of a land right in accordance with the legal provisions and the PPAT makes a Sale and Purchase Deed which is then followed by registration at the local Land Office in accordance with the location where the land is the object of the sale and purchase. ${ }^{4}$

One of the conditions in making a certificate for the transfer of rights through buying and selling is the payment of taxes. Taxes in land sales transactions are as follows:

1. Income tax, namely the collection of income tax (PPh) imposed on the seller based on Government Regulation number 48 article 1 paragraph (1) of 1994 which regulates the payment of income tax on income from the transfer of rights to land or buildings. The amount of PPh from the transfer of rights to land and / or buildings is $2.5 \%$ of the gross amount of the value of the transfer of rights to land and / or buildings.

2. PPN

\footnotetext{
${ }^{1}$ Dyara Radhite Oryzafea, 2018, Guide to Managing Land and Licensing Houses, Legality, Jakarta, p. 2 ${ }^{2}$ Ibid, p. 130

${ }^{3}$ JB Daliyo et al, 2001, Agrarian Law I, printing 5, Prehallindo, Jakarta, p. 80

${ }^{4}$ Rafiq Adi Wardana, Cancellation of the Deed of Sale and Purchase of PPAt with Legal Disabilities with a Court Decision, journal of the Faculty of Law, Sebelas Maret University, Surakarta, p. 2
} 
3. If the buyer makes a land purchase transaction with a developer or entity that is a Taxable Entrepreneur (PKP), the buyer will be subject to VAT collection at a rate of $10 \%$ of the land price. However, if the seller is not PKP, then the buyer must pay his own VAT to the state treasury.

4. BPHTB

5. Acquisition Fees for Land and Building Rights are levies borne by the buyer. Regulations regarding the imposition of BPHTB can be seen in Act Number 20 of 2000 concerning Amendments to Act Number 21 of 1997 concerning Fees for the Acquisition of Rights to Land and Buildings. The amount of the BPHTB rate is $5 \%$ of the NJOP which has been deducted by the Acquired Value of the Non-Taxable Tax Object.

Presidential Regulation Number 34 of 2016 specifically regulates Income Tax on income derived from land transactions. Require every transaction that is not exempted (exceptions are stated in Article 6), to deposit its Income Tax before signing the deed or other written evidence by the authorized official. Deposits use a Tax Deposit Letter (SSP) PPh or printed out other administrative facilities, equivalent to SSP. Proof of payment must be reported and researched, and validated by the local KPP (Article 3 paragraph (5) of Presidential Regulation Number 34 of 2016). ${ }^{5}$

The cancellation of the sale and purchase process results in a return to its original state, that is, all fees that have been paid must be returned to each party, including in this case the Final Income Tax paid by the seller. This is a form of restitution for the overpayment of taxes. Based on the background of the problem above, the author is interested in conducting research and compiling it in a thesis entitled "A Juridical Review of Income Tax Restitution (PPH) on the Cancellation of Purchase and Sale Binding Agreements Based on Government Regulation Number 34 of 2016".

This study aims to determine and analyze the legal construction of the Sale and Purchase Binding Agreement which is the basis for the imposition of Income Tax (PPh). Implementation The Sale and Purchase Agreement of Land Rights Related to the Imposition of Income Tax (PPh) and the Income Tax (PPh) restitution (return) procedure for the cancellation of the sale and purchase agreement based on Government Regulation Number 34 of 2016.

\section{Research methods}

This study uses a normative juridical approach. Data collection is done by collecting primary legal materials, legal materialssecondary, and tertiary legal materials. ${ }^{6}$ The data collection techniques using interview methods and literature study. Then processed and analyzed using qualitative analysis methods and then the method of drawing conclusions using the deductive method, namely thinkingfrom general

\footnotetext{
${ }^{5}$ https://irmadevita.com, accessed March 2, 2020, at 12.30 WIB

${ }^{6} \mathrm{H}$. Zainuddin Ali, 2009, Legal Research Methods, Sinar Grafika, Jakarta, p. 47
} 
matters lead to specific or specific things by using normative tools so that they can provide clear answers to problems and research objectives. ${ }^{7}$

\section{Results and Discussion}

\subsection{The legal construction of the Sale and Purchase Agreement which is the basis for the imposition of Income Tax (PPh)}

Taxes are a source of state revenue that comes from people's contributions to the State treasury. This tax collection is based on enforceable law without receiving compensation services (counter-achievement) that can be directly demonstrated and used to pay for general expenses and construction of public facilities as mutually agreed upon. Taxes are currently one of the largest sources of national development revenue in order to achieve prosperity for its citizens. ${ }^{8}$ The legal basis for the application of tax levies in Indonesia is based on the provisions of the third amendment to the 1945 Constitution of the Republic of Indonesia, Article 23 letter a, which states that "Taxes and other levies that are compulsive for State purposes are regulated in law."

One form of transfer of rights to land and / or buildings is buying and selling. In the sale and purchase transaction of land and / or buildings, the objects are land and buildings, while the parties who are subject to tax are the seller and the buyer. The obligation to pay income tax taxes is borne by the seller as receiving income.

Payment of income tax has a close relationship with the process of signing the sale and purchase deed, because the signing of the sale and purchase deed will only be done when tax payments by both parties have been completed. Tax payments are considered complete if they have gone through a formal and material research process by the Tax Service Office. In formal and material research, the tax value payable will be determined based on the actual value received by the taxpayer or the value that should be received by the seller. This is regulated in Article 2 paragraph (2) letter $c$ and letter d of Government Regulation Number 34 of 2016:

1. The value of the transfer of rights to land and / or buildings is the value actually received or obtained, in the event that the transfer of rights to land and / or buildings is carried out through a sale and purchase which is not affected by a special relationship.

2. The value of the transfer of rights to land and / or buildings is the value that should be received or obtained in the event that the transfer of rights to land and / or buildings is carried out through a sale and purchase which is influenced by a special relationship.

Based on these provisions, there are two conditions for determining the transfer value in a sale and purchase transaction, namely a condition where there is a special

\footnotetext{
${ }^{7}$ Soerjono Soekanto and Sri Mamudji, 1995, Normative Legal Research, A Brief Overview, Raja Grafindo Persada, Jakarta, p. 23.

${ }^{8}$ Chidir Ali, 1993, Elementary Tax Law, Eresco Publisher, Bandung, p. 1
} 
relationship between the seller and the buyer, and a condition where there is no special relationship between the seller and the buyer. In the absence of a special relationship in accordance with the income tax principle, namely tax is imposed on income received by the taxpayer.

However, if there is a special relationship, there is an indication that the sale and purchase value on which the tax is based is below the actual price. Indications of the sale and purchase value that do not correspond to market prices are often found in the process of examining material evidence of fulfillment of the income tax payment obligations on income from the transfer of rights to land and / or buildings. ${ }^{9}$

Based on Article 1 of Act Number 36 of 2008 concerning Income Tax, it is a tax imposed on tax subjects on income received in the tax year. The tax subject will be taxed if he receives or earns income. In the Income Tax Law, tax subjects who receive or earn income are referred to as taxpayers. Before conducting a sale and purchase transaction, the parties are obliged to ensure that the land is not in dispute. If the land is in dispute, the Land Deed Making Officer (PPAT) has the authority not to continue the sale and purchase process.

In the sale and purchase transaction stage, the seller is required to complete the following requirements:

1. Photocopy of KTP (if you are married, you must include a photocopy of your partner's KTP).

2. Family Card (KK).

3. Taxpayer identification number (NPWP).

4. Original Certificate of Land Rights to be sold includes (Ownership Certificate, Building Use Right Certificate, Certificate, Business Use Rights, Ownership Certificate for Flats).

5. Proof of payment of Land and Building Tax (PBB) for the last 5 years along with the Tax Payable Tax Return (SPPT) for the last year.

6. Indonesian citizen certificate or name change, if the seller is an Indonesian citizen with descent.

7. Proof of husband and wife consent (for those who are married).

8. If the husband / wife has passed away, a death certificate must be attached.

Before the sale and purchase deed is signed by the parties, the seller must pay income tax with the following calculation: (Income tax = actual / should be received $\times 2.5 \%$ ) While the buyer must pay the Acquisition Fee for Land and / or Building Rights (BPHTB). ${ }^{10}$

Legal Basis for Imposition of Income Tax on Transfer of Rights to Land and / or Buildings The legal basis used is the Income Tax Act Number 36 Of 2008 Article 4 paragraph 2 letter $d$. In this article, it is clearly stated that income obtained from

9I Gusti Ngurah Bagus, Simon Nahak and Ni Luh Made Mahendrawati, Legal Certainty of Tax Imposition of Land and / or Building Transactions, Prasada Legal Journal, Vol. 6, No. 1, March 2019, pp. 42-51, p. 5 ${ }^{10}$ Ibid 
transactions of transfer of rights to land and / or buildings may be subject to final income tax. It is said that income tax can be imposed because there is also income from transactions of transfer of rights to land and / or buildings that are exempted from income tax. So in general, income derived from transactions of transfer of rights to land and / or buildings is subject to final income tax unless otherwise stipulated.

In order to calculate income tax in the form of Final Income Tax Article 4 paragraph 2 from a transaction of transferring rights to land and / or buildings, it is necessary to know the rate and the tax object. The rate of Final Income Tax Article 4 paragraph 2 from transactions for the transfer of rights to land and / or buildings in general is $5 \%$. Meanwhile, the tax object is the income obtained from the transaction. The formula is: Final Income Tax Article 4 paragraph (2) $=5 \% \times$ Gross income from transfer of rights to land and / or buildings. Because the tax object is income from buying and selling land and / or buildings, two terms are known, namely NJOP Value and value on the Deed of Transfer of Rights. Therefore it is further determined that the value used is the highest value between NJOP and the Deed of Transfer of Rights,

\subsection{Implementation of the Sale and Purchase Agreement of Land Rights Related to Income Tax (PPh)}

Taxes are the main source of income for the State and are a manifestation of the implementation of obligations as citizens in participating in financing the development of the State which is increasing in line with the progress of the times and the increasing number of population. Tax as the main source of income for state financing has several functions, the function of the tax consists of a budget function, a regulatory function and a social function. ${ }^{11}$ The process of transferring rights to land and / or buildings is closely related to legal certainty in order to become evidence of transfer of rights so that these rights can be maintained against all parties, and in the process of transferring rights to land and / or buildings, there are rights and obligations for the party transferring or the party who receives the transfer of rights. ${ }^{12}$

A process of transferring land rights according to the Basic Agrarian Law (UUPA) must be carried out in a clear and cash manner. This means that the transaction price must be paid in full by the buyer. Meanwhile, the clear must be done with a PPAT deed, in this case a sale and purchase deed (AJB), after both material and formal requirements have been met. In the process of the Agreement on Sale and Purchase of Land Rights, the parties come to the notary to state that one party will sell their land rights to the other party. Basically, this only begins with consultation between the two of them to the notary, to find out the requirements that will be needed in making Sale and Purchase Agreement (PPJB), and in the next stage the notary will provide requirements that must be met by one and / or both parties, including: $\left.{ }^{13} 1\right)$ Original Certificate of Land Rights; 2) Photocopy of Family Card; 3) Proof of Land and Building Tax Payment;

\footnotetext{
${ }^{11}$ Tunggul Anshari Setia Negara, 2017, Tax Law, Setara Press, Malang, p. 5

12 Luh Putu Sudini, Imposition of Taxes on the Sale and Purchase Agreement of Land Rights, Journal of Law Volume 16 Number 1 February 2020 - July 2020, p. 117

13 Interview with Ari Hermawan Notary and PPAT in Semarang, 20 Jull 2020
} 
and 4) Photocopy of Identity Card (For Buying Party). After these requirements are completed, the parties who have agreed to carry out this sale and purchase transaction are also bound by a Sale and Purchase Agreement (PPJB) to provide legal certainty for both the seller and the buyer so that there is no unilateral cancellation or minimizing risks in buying and selling. . ${ }^{14}$

This Sale and Purchase Agreement (PPJB) is made with the following versions: ${ }^{15}$

1. The new Sales and Purchase Agreement are promises because the transaction has not been paid in full and there is no power of attorney in it, except for the fulfillment of an obligation.

2. A Sale and Purchase Agreement that has been paid in full, but the Sale and Purchase Deed (AJB) cannot be made in the presence of the authorized Land Deed Making Official, because there is still a process that has not been completed.

In the making of the Sale and Purchase Agreement, where the payment is made in full, this is accompanied by a deed of power to sell, from the seller to the buyer which functions as legal protection for buyers who have paid in full but have not been able to process the Deed of Sale and Purchase (AJB) before Land Deed Making Official (PPAT) because there are requirements that have not been met. The purpose of making a Sale and Purchase Agreement (PPJB) is to check certificates, check zones or land values that affect the payment of Land and Building Tax (PBB), and also to find out how much Income Tax payments or also known as PPh for the seller and Tax on Acquisition of Rights to Land and / or Buildings (BPHTB) for the buyer.

According to Article 37, Government Regulation Number 24 of 1997, the Sale and Purchase Deed must be made by the Official for Making Land Deeds (PPAT), after the parties fulfill the material requirements consisting of ${ }^{16}$

1. The buyer who has the right to buy the land concerned, in terms of meeting the requirements to own the land to be purchased, is as described in Article 21 of the UUPA where land ownership rights can only be owned by a single Indonesian citizen and a legal entity determined by the government.

2. The seller who has the right to sell the land in question, what is meant here is the legal holder of the land to be traded, according to the name that has been stated in the land certificate.

3. Land that can be traded and not in dispute. Then, the transfer of new rights occurs after a sale and purchase is carried out in front of the Land Deed Making Official (PPAT), so that it can be said that the land sale and purchase has been completed with the deed maker by the Land Deed Making Official (PPAT) and the deed of the Land Deed Making Official (PPAT) is evidence that there has been a sale and purchase, namely that the buyer has become the owner of the new land rights. Furthermore, the ratification of the land title sale and

\footnotetext{
14 Ibid

15 Ibid

${ }^{16}$ Adrian Sutedi, 2010, Transfer of Land Rights and Registration, Sinar Grafika, Jakarta, p. 34
} 
purchase agreement as long as all subjective and objective requirements are fulfilled perfectly.

\subsection{Income Tax (Pph) Restitution (Return) Procedure against the Cancellation of the Sale and Purchase Agreement based on Government Regulation Number $\mathbf{3 4}$ of 2016}

Tax refunds are generally related to the taxpayer's right to get a refund that has been paid. Tax refunds occur because of overpaid taxes or taxes that are not payable but have already been paid. Restitution can be made on all types of taxes that occur due to overpayment of taxes, or tax collection and therefore the taxpayer is entitled to receive a refund of the excess payment. In accordance with the principle of justice, that taxpayers who pay less taxes will be subject to billing and fines, on the other hand, if there is an overpayment of taxes, they must be returned. ${ }^{17}$

Tax refund is a tax refund request submitted by taxpayers to the state. The term tax restitution is contained in the KUP Law. In simple terms, in a state tax refund pay back or return the tax that has been paid by the taxpayer. Tax refund only occurs if the amount of tax credit or the amount of tax paid is greater than the amount of tax due or has been paid taxes that are not supposed to be due, provided that the taxpayer has no other tax payable. ${ }^{18}$

Tax restitution aims to protect the rights of taxpayers. The reporting of tax overpayments is also a guarantee of the trust given by the government to taxpayers. In April 2018, the government through the finance ministry issued a new regulation aimed at accelerating the provision of levies to taxpayers who are entitled and meet the criteria. The determination of the criteria is also obtained through simple research and without having to go through an examination.

The following are the requirements that must be met by taxpayers to get the acceleration of giving income tax refunds: ${ }^{19}$

1. Individual taxpayers who have an overpayment of less than or equal to Rp.100 million. Second, overpaying corporate taxpayers below or equal to Rp1 billion. Third, PKP with an overpayment of less than or equal to Rp1 billion.

2. Taxpayers who are on time in submitting SPT, do not have tax arrears, have audited financial statements and get unqualified opinion (WTP) for 3 consecutive years, and have never been convicted in the field of taxation in the last 5 years.

3. Low-risk PKP established by the minister of finance. In this case the PKP is a public company (go public), BUMN / BUMD, main partner exporter of customs (MITA) or reputable trader whose profile is owned by the Directorate General of Customs and Excise.

\footnotetext{
${ }^{17}$ Y. Sri Pudyatmoko, Op.Cit, p. 185

18 https://www.online-pajak.com/restitution-pajak, accessed on 16 August 2020, at 21.00 WIB

19 Interview with Indah Lestari Tax Officer in Semarang, July 28, 2020
} 
The mechanisms and stages of the tax restitution process are relatively the same. However, regarding the preliminary restitution, the document verification process was made easier, only through simple administrative research. However, that does not mean that the examination is abolished. This process is only postponed after the preliminary restitution has been granted. Thus, it does not eliminate the consequences of administrative sanctions in the form of an increase of $100 \%$ from the basis of tax determination if based on the results of the audit it is found that underpayment of taxes is found. So, make sure the books and supporting evidence are complete when applying for restitution. ${ }^{20}$

In addition to reducing the tax tax audit burden, returning the tax overpayment will also reduce the burden of interest compensation that must be paid by the Government to taxpayers. Article 11 paragraph 3 of the KUP Law states: "If the refund of the overpayment of tax is made after a period of 1 (one) month, the Government will provide an interest compensation of $2 \%$ (two percent) per month for the late restitution ..." Then, it is reaffirmed in Article 17B paragraph 4 UU KUP: "... Taxpayers are given bunqa compensation of $2 \%$ (two percent) per month for a maximum of 24 (twenty four) months, calculated from the end of the 12 (twelve) month period ..." Acceleration of restitution should apply equally systemically, regardless of the status and track record of the Taxpayer.

\section{Closing}

\subsection{Conclusion}

Based on the description above, the conclusions in this research are:

1. The legal construction of the Sale and Purchase Agreement which is the basis for the imposition of Income Tax (PPh) is the Income Tax Act Number 36 Of 2008 Article 4 paragraph 2 letter $\mathrm{d}$. In this article, it is clearly stated that income obtained from transactions of transfer of rights to land and / or buildings may be subject to final income tax. It is said that income tax can be subject to income tax because there is also income from transactions of transfer of rights to land and / or buildings that are exempted from income tax, the rate and tax object are known. The rate of Final Income Tax Article 4 paragraph 2 from transactions for the transfer of rights to land and / or buildings in general is $5 \%$. Meanwhile, the tax object is the income obtained from the transaction.

2. Implementation of the Sale and Purchase Agreement of Land Rights Related to the Imposition of Income Tax (PPh) hThe flow is clear, namely based on the agreement of both parties, and is carried out with a PPAT deed, in this case a sale and purchase certificate (AJB), after both material and formal requirements have been met. In the process of the Agreement on Sale and Purchase of Land Rights, the parties come to the notary to state that one party will sell their land rights to the other party. Basically, this only begins with consultation between the two of them to the notary, to find out the

\footnotetext{
20 Interview with Indah Lestari Tax Officer in Semarang, July 28, 2020
} 
requirements that will be needed in making Sale and Purchase Agreement (PPJB)

3. The Income $\operatorname{Tax}(\mathrm{PPh})$ restitution (return) procedure for the cancellation of the sale and purchase agreement based on Government Regulation Number 34 of 2016, the mechanisms and stages of the tax restitution process are relatively the same. However, regarding the preliminary restitution, the document verification process was made easier, only through simple administrative research. However, that does not mean that the examination is abolished. This process is only postponed after the preliminary restitution has been granted. Thus, it does not eliminate the consequences of administrative sanctions in the form of an increase of $100 \%$ from the basis of tax determination if based on the results of the audit it is found that underpayment of taxes is found. Make sure the books and supporting evidence are complete when applying for restitution.

\subsection{Suggestion}

Based on the description above, the conclusions in this research are:

1. In terms of making a regulation, the government should first review all related regulations so that there is no conflict between rule one and regulation

2. To the public to pay attention that in terms of juridical evidence of the transfer of land rights, it is not only limited to the Sale and Purchase Agreement (PPB) and the Sale and Purchase Agreement (AJB), but for the sake of legal certainty for third parties, it is better if the Sale and Purchase Deed is issued. (AJB) was immediately taken care of regarding the reversal of the name on the land title certificate.

\section{References}

Journal:

[1] I Gusti Ngurah Bagus, Simon Nahak and Ni Luh Made Mahendrawati, Legal Certainty of Tax Imposition of Land and / or Building Transactions, Prasada Legal Journal, Vol. 6, No. 1, March 2019, pp. 42-51

[2] Luh Putu Sudini, Imposition of Taxes on the Agreement of Sale and Purchase of Land Rights, Journal of Law Volume 16 Number 1 February 2020 - July 2020

[3] Rafiq Adi Wardana, Cancellation of the Deed of Sale and Purchase of PPAt with Legal Disabilities with a Court Decision, journal of the Faculty of Law, Sebelas Maret University, Surakarta

Books:

[1] Adrian Sutedi. (2010). Transfer of Land Rights and Registration, Sinar Grafika, Jakarta

[2] Sudikno Mertokusumo. (2009). Invention of Law, Citra Aditya Bakti, Bandung 
[3] Mahmud Marzuki. (2008). Introduction to Legal Studies, Kencana Pranada Media Group, Jakarta

[4] Suharsini Arikunto. (2006). Research Procedures for a Practical Approach, Eleventh Printing, Rineka Cipta, Jakarta

[5] Dyara Radhite Oryzafea. (2018). Guide to Managing Land and Licensing Houses, Legality, Jakarta

[6] JB Daliyo et al. (2001). Agrarian Law I, imprint 5, Prehallindo, Jakarta

[7] H. Zainuddin Ali. (2009). Legal Research Methods, Sinar Grafika

[8] Soerjono Soekanto and Sri Mamudji. (1995). Normative Legal Research, A Brief Overview, Raja Grafindo Persada, Jakarta

[9] Chidir Ali. (1993). Elementary Tax Law, Eresco Publisher, Bandung

[10] Tunggul Anshari Setia Negara. (2017). Tax Law Science Setara Press, Malang

[11] Adrian Sutedi. (2010). Transfer of Land Rights and Registration, Sinar Grafika, Jakarta

Internet:

https://www.online-pajak.com/restitution-pajak

Regulations:

[1] The 1945 Constitution of the Republic of Indonesia

[2] Act Number 36 of 2008 concerning Income Tax

[3] Act Number 2 of 2014 concerning Notary Position

[4] Act Number 5 of 1960 concerning Basic Agrarian Regulations

[5] Regulation of the Minister of Agrarian Affairs No Permen ATR Number 21 of 2017 concerning Confirmation of Taxpayer Status in Land Services within the Ministry of Agrarian Affairs and Spatial Planning / National Land Agency.

[6] Government Regulation Number 34 of 2016 concerning Income Tax on Income from Transfer of Rights to Land and / or Buildings, and Agreement on Sale and Purchase of Land and / or Buildings. 